\title{
ROZBUDOWA UZDROWISKA W KRYNICY W LATACH 1806-1830 W ŚWIETLE AKT GUBERNIUM LWOWSKIEGO
}

\author{
Michał Baczkowski iD http://orcid.org/0000-0002-9717-1046 \\ Uniwersytet Jagielloński w Krakowie
}

\begin{abstract}
EXTENSION TO THE HEALTH RESORT IN KRYNICA IN 1806-1830 IN THE LIGHT OF THE FILES OF THE LVIV GOVERNORATE
\end{abstract}

The Austrian authorities in Galicia sought to use the mineral springs existing in that land. Krynica was one of the few state-owned villages that had mineral springs. The health resort was founded in 1793. But it was only the investments from 1806-1810 that transformed the village into a real health resort. In 1811, further works were stopped, and after a few years they were resumed to a very limited extent. The main reason for the lack of new investments was the financial crisis of the state related to the Napoleonic wars.

Hopes for a quick transformation of Krynica into the main health resort of Galicia, to which Poles would also come from abroad (Russia, Prussia, the Duchy of Warsaw - later the Kingdom of Poland), ended in failure. The high number of visitors recorded in the first years of the $19^{\text {th }}$ century soon declined. Krynica lost the competition with other spas in Southern Poland (Krzeszowice, Swoszowice), as well as with resorts in the Kingdom of Bohemia and in Hungary. Only in the second half of the $19^{\text {th }}$ century, Krynica became the largest spa in Galicia, and one of the most important in Austria. However, this took place under completely different socioeconomic circumstances.

Keywords: Galicia, Krynica, Polish health resorts, $19^{\text {th }}$ century.

Słowa kluczowe: Galicja, Krynica, uzdrowiska polskie, XIX wiek.

Rozwój uzdrowisk należał na przełomie XVIII i XIX wieku do ważniejszych zadań austriackiej administracji prowincjonalnej. Nie budziło to większych wątpliwości, gdyż na początku XIX stulecia monarchia habsburska znajdowała się w ścisłej czołówce europejskiej pod względem eksploatacji źródeł mineralnych, a takie kurorty jak Karlsbad (Karlowe Wary), Marienbad (Mariańskie Łaźnie) czy Franzensbad (Franciszkowe Łaźnie) odwiedzane były przez europejską arystokrację i członków 
rodzin panujących. Również uzdrowiska węgierskie (szczególnie położone na Górnych Węgrzech), znacznie skromniejsze, cieszyły się dość znaczną popularnością, także wśród Polaków, a wynikało to między innymi ze względnej taniości pobytu i niezbyt dużej odległości od stałych miejsc ich zamieszkania.

$\mathrm{Na}$ tym tle Galicja wypadała bardzo blado. W chwili I rozbioru Polski nie istniał tu żaden kurort z prawdziwego zdarzenia. Nic też dziwnego, że jednym z zadań nowych austriackich władz gubernialnych było ustalenie wartości i zbadanie stanu chemicznego znanych już wcześniej źródeł mineralnych, a następnie przekształcenie zapadłych wiosek, dysponujących zdrojami, w nowoczesne uzdrowiska. W praktyce możliwości władz były bardzo ograniczone, gdyż większa część źródeł mineralnych znajdowała się na terenach prywatnych. Gdy jednak występowały one na ziemiach wchodzących w skład dóbr kameralnych, to administracja państwowa nie była już tak bardzo skrępowana stosunkami własnościowymi. Mogła też (i powinna) zainicjować tworzenie uzdrowiska.

Do takich właśnie ośrodków należała Krynica. Jej źródła mineralne zostały zbadane w 1788 roku oku przez Balthasara Hacqueta ${ }^{1}$, który je bardzo wysoko ocenił. Kilka lat później, w 1793 roku, rozpoczęto tu zakładanie uzdrowiska². Sama wieś należała do dominium kameralnego w Muszynie, które w 1801 roku włączono do Funduszu Religijnego, w związku z czym naturalnym inwestorem pozostało państwo ${ }^{3}$. Prywatni przedsiębiorcy nie mieli tu czego szukać. Najwyżej mogli uczestniczyć w przetargach na dostawę niezbędnych materiałów do budowy kurortu, a następnie liczyć na ewentualną dzierżawę istniejącej już infrastruktury państwowej. Do wyłącznych zadań Gubernium Galicyjskiego należała rozbudowa i utrzymanie uzdrowiska, rozpropagowanie go wśród potencjalnych kuracjuszy oraz składanie stosownych sprawozdań do Wiednia (w praktyce do Kamery Nadwornej).

Zachowany materiał archiwalny przechowywany w zbiorach Centralnego Państwowego Archiwum Historycznego Ukrainy we Lwowie daje dość dobry wgląd w działania administracji austriackiej względem Krynicy w latach 1806-1830. Jest

${ }^{1}$ Balthasar Hacquet de la Motte (1739-1815), austriacki chemik, botanik, geograf, etnolog. Od 1787 r. był profesorem historii naturalnej na uniwersytecie lwowskim, w 1. 1805-1810 był profesorem na uniwersytecie krakowskim, od 1807 r. dziekanem Wydziału Medycznego. Autor licznych prac dotyczących m.in. geografii i botaniki Galicji. C. von Wurzbach, Biographisches Lexikon des Kaiserthums Oesterreich, Bd. VII, Wien 1861, s. 163-165; Österreichisches Biographisches Lexikon 1815-1950, Bd. 2, Wien 1959, s. 132-133.

${ }^{2} \mathrm{Na}$ temat początku i faz rozwoju uzdrowiska w Krynicy powstała już znaczna literatura, ale po 1939 r. nie korzystano w ogóle z archiwaliów lwowskich, a we wcześniejszym okresie zużytkowano je w sposób wybiórczy, zob. M.J. A da mczyk, Wieś i osada zdrojowa w okresie austriackim [w:] Krynica, red. F. Kiryk, Kraków 1994, s. 199-219; M. Zieleniewski, Materiały do historii Zakładu Zdrojowego w Krynicy, „Krynica” 1876, nr 9-12; B. Skórczew ski, Historia Krynicy, „Przegląd Zdrojowy” 1906, nr 6-7; F. Kmietowicz, Z Podkarpacia Zachodniego, Kraków 1936, s. 9-15; L. Rajche1, J. Rajchel, Krynica-Zdrój-historia uzdrowiska, „Borgis-Balneologia Polska” 2005, nr 1-2, s. 60-64; B. Hacquet, Hacquet's neueste physikalisch-politische Reisen in den Jahren 1788-1795 durch die Dacischen und Sarmatischen oder Nordlichen Karpathen, Teil IV, Nürnberg 1796, s. 118-124.

${ }^{3}$ K. Ślusarek, W przededniu autonomii. Własność ziemska i ziemiaństwo w Zachodniej Galicji w połowie XIX wieku, Kraków 2013, s. 39-40. Dobra państwowe w Galicji w pierwszej poł. XIX w. dzieliły się na: kameralne, Funduszu Religijnego oraz Dyrekcji Salinarnej w Wieliczce. 
to okres ciekawy, pod względem politycznym dzielący się na dwie epoki: czas wojen napoleońskich (do 1815 r.) oraz kilkunastoletni okres pokoju, zakończony wybuchem fali rewolucyjnej w 1830 roku. W tym też czasie nastąpiła zasadnicza faza budowy samego uzdrowiska, a następnie pierwszy okres jego normalnego funkcjonowania. Istniejące archiwalia są zróżnicowane poznawczo i dalekie od kompletności, dają jednak ogólny obraz zamierzeń administracji austriackiej, sposobu rozbudowy uzdrowiska i związanych z tym kontrowersji, jak również pokazują wyniki tych działań mierzone liczbą, pochodzeniem społecznym i geograficznym gości uzdrowiska. Niniejszy tekst nie ma na celu omówienia wszelkich spraw związanych z zakładaniem zdroju, a jedynie przedstawienie jego faz rozwojowych i koncepcji rozbudowy zapisanych w aktach lwowskiego Gubernium ${ }^{4}$.

W świetle zachowanych dokumentów administrację austriacką zajmowały szczególnie następujące kwestie:

- budowa i utrzymanie podstawowej infrastruktury uzdrowiskowej;

- zwiększenie atrakcyjności kurortu jako miejsca spędzania wakacji (sezonu letniego);

- rozpropagowanie Krynicy jako uzdrowiska wśród potencjalnych kuracjuszy w kraju i za granicą (Królestwo Polskie, Wolne Miasto Kraków, Ziemie Zabrane) Te trzy zasadnicze problemy stale przewijają się w zachowanym materiale źródłowym i warte są dokładniejszej interpretacji.

Kwestia budowy infrastruktury uzdrowiskowej oraz połączenia Krynicy z galicyjską siecią drożną była decydująca dla całego rozwoju kurortu. Dlatego też władze gubernialne poświęciły temu problemowi wiele uwagi. Raporty i memoriały z 1806 roku (jeden z nich autorstwa Josepha Augusta Schultesa ${ }^{5}$ ) kładły nacisk na konieczność skomunikowania Krynicy z innymi częściami Galicji gościńcem przez Nowy Sącz, a stamtąd w kierunku Myślenic, Gdowa, Bochni, Wojnicza, Tarnowa, Rzeszowa, Przemyśla, czyli krótko mówiąc: z głównymi węzłami komunikacyjnymi galicyjskiego traktu cesarskiego i z miastami cyrkularnymi. Najważniejszą kwestią było zbudowanie łącznika z Krynicy do drogi powiatowej (cyrkularnej) Nowy Sącz-Krzyżówka-Tylicz-Muszynka-granica węgierska, którą nieznacznie

${ }^{4}$ Центральний державний історичний архів України, Львів [Centralne Państwowe Archiwum Historyczne Ukrainy we Lwowie, dalej: CPAHUL], fond 146, op. 77, spr. 13-14. Z datą początkową (1806) związany jest nadto półurzędowy opis Krynicy autorstwa Josepha Augusta Schultesa (J.A. Sc hultes, Über die Mineralquellen zu Krynica in Sandezer Kreis, Wien 1807), zob. S. Schnür-Pepłowski, Cudzoziemcy w Galicji (1787-1841), Kraków 1902, s. 113-114, 142-146. Część materiałów archiwalnych wykorzystał w drugiej połowie XIX w. Michał Zieleniewski w cyklu artykułów zamieszczonych w krynickim tygodniku uzdrowiskowym „Krynica” (M. Zieleniew ski, Materiały do historii Zakładu Zdrojowego w Krynicy), a na początku XX w. Bolesław Skórczewski w cyklu tekstów poświęconych uzdrowisku w Krynicy (B. Skórczew ski, Historia Krynicy). Dane zamieszczone w tych pracach wskazują na znacznie obszerniejszy zasób archiwalny dotyczący Krynicy niż istniejący obecnie. Pierwszy opis uzdrowiska w Krynicy w języku polskim został zamieszczony w 1811 r. w „Dodatku” do „Gazety Lwowskiej" 1811, nr 1, 2 IV, s. 1-4.

5 Joseph August Schultes [Schulthes] (1773-1831), austriacki przyrodnik i botanik, w 1. 1806-1808 profesor uniwersytetu krakowskiego, autor licznych prac dotyczących geografii Alp, mineralogii i chemii. Zwolennik Napoleona, szykanowany przez władze austriackie w 1809 r.; C. von Wurzbach, Biographisches Lexikon des Kaiserthums Oesterreich, Bd. XXXII, Wien 1876, s. 171-176. 
ulepszono w 1804 roku. Istniejąca droga Krynica-Krzyżówka była nieodpowiednia dla gości uzdrowiska, gdyż była bardzo stroma, a ponadto brakowało na niej mostów. W związku z tym zaplanowano nowy przebieg tej drogi, dostosowanej do zwiększonego ruchu kuracjuszy. Kwestia ta była elementem szerszego problemu modernizacji dróg powiatowych w Galicji: niektóre z nich już rozbudowano, przy części z nich prowadzono roboty, budowa innych była dopiero w planach ${ }^{6}$.

Przebudowę drogi prowadzącej do Krynicy podjęto w 1807 roku, o czym Gubernium informowało Kamerę Nadworną pismem z 6 maja 1808 roku Powołując się na ustalenia specjalnej komisji z 29 grudnia 1806 roku, naprawiono istniejący wówczas gościniec i uregulowano potok Słotwinka kosztem $7526 \mathrm{fl}^{7}$. Zapewne prace te uznano za wystarczające, gdyż w późniejszej dokumentacji brak materiałów na ten temat, a jedyne wzmianki o rozbudowie sieci drożnej dotyczyły już samej Krynicy.

Nie mniej istotnym zadaniem była rozbudowa infrastruktury uzdrowiskowej. Bliższe informacje na ten temat zostały zawarte w dekrecie Kamery Nadwornej z 12 marca 1807 roku podpisanym przez jej prezydenta, hr. Karla Zichy'ego, a skierowanym do Gubernium. Dotyczył on utrzymania źródeł mineralnych w odpowiednim stanie oraz zapewnienia gościom miłego pobytu w Krynicy, czyli zorganizowania regularnego uzdrowiska. Dekret zakładał konieczność budowy domu zdrojowego oraz zatrudnienia lekarza zdrojowego, którego utrzymanie miało wynieść $400 \mathrm{fl}$ rocznie, oraz dostarczenia mu mieszkania na sezon kąpielowy. Należało także wznieść budynek gościnny (Wirthaus) z jedną salą publicznie dostępną (balową) i 12 pokojami dla gości. Za rozbudowę uzdrowiska miała odpowiadać komisja w składzie: protomedyk Franz de Paula Neuhauser, inspektor kameralny Andreas Nossberg (właściwie Andreas Noss von Nossberg) oraz sądecki (właściwie tarnowski) inżynier powiatowy Bonawentura Losi von Lusenau. W dekrecie znalazł się także zapis o konieczności zorganizowania akcji promującej przybywanie do Krynicy mieszczan z okolicznych miast i z Krakowa oraz o planach wydzierżawienia uzdrowiska (wraz z prawem propinacji i prowadzenia traktierni) poważnemu przedsiębiorcy, o czym należało publicznie poinformować za pomocą ogłoszeń w gazetach czeskich i morawskich ${ }^{8}$.

Kolejne działania władz państwowych szły dwutorowo: z jednej strony skupiono się na wykupie prywatnych działek chłopskich i parafialnych w celu poszerzenia uzdrowiska, z drugiej zaś strony na konkretnych inwestycjach budowlanych i instytucjonalnych.

Struktura własnościowa była w Krynicy dość skomplikowana, podobnie jak i w innych wsiach galicyjskich. Pomimo że miejscowość należała do dóbr Funduszu Religijnego, to bezpośrednio w rękach państwa znajdowały się tylko pojedyncze

${ }^{6}$ CPAHUL, fond 146, op. 77 , spr. 13, s. 1-31.

7 Ibidem, s. 92

${ }^{8}$ Ibidem, s. 39. Alternatywny skład komisji podali Bolesław Skórczewski i Stanisław Schnür-Pepłowski: profesor Joseph August Schultes, starosta sądecki i radca gubernialny Franz von Ridelswald, inspektor kameralny Andreas Nossberg, inżynier cyrkularny sądecki Ehrenberth von Moll i zarządca dóbr kameralnych w Muszynie Adam Rihm. B. Skórczew ski, Historia Krynicy, „Przegląd Zdrojowy” 1906, nr 6, s. 3; S. Schnür-Pepłows ki, Cudzoziemcy w Galicji, s. 143; zob. też: Schematismus für die Königreiche Galizien und Lodomerien für das Jahr 1807, Lemberg 1807, s. 68, 70, 102-103. 
działki i obiekty (np. murowana karczma dominialna). Pozostałe ziemie należały do probostwa greckokatolickiego i do chłopów. 14 lipca 1808 roku Kamera Nadworna wydała zgodę na wyasygnowanie $5000 \mathrm{fl}$ na wykup (zapewne przymusowy) gruntów i budynków chłopskich w Krynicy ${ }^{9}$. Ziemia i zabudowania należące do Jerzego Michałowicza z Krynicy zostały wywłaszczone i opłacone przez Fundusz Religijny z Muszyny. Doszło przy tym do poważnych nieporozumień, gdyż właściciel miał otrzymać $5000 \mathrm{fl}$, natomiast kasa wypłaciła mu tylko 500 fl. Nastąpiła w tej sprawie interwencja ze strony Gubernium, gdyż grunty te miały być przekazane następnie dzierżawcy Hofmannowi i graniczyły bezpośrednio z karczmą dominialną, w związku z czym należało ten problem szybko rozwiązać ${ }^{10}$. Do kolejnej transakcji doszło dwa lata później, a została ona zatwierdzona 14 lipca 1810 roku przez Kamerę Nadworną. W myśl umowy Fundusz Religijny nabył 3 morgi 1579 sążni ziemi od parocha greckokatolickiego, ks. Antoniego Krynickiego na potrzeby rozbudowy uzdrowiska w Krynicy. Kontrakt miał mieć charakter bezgotówkowy i dotyczył wymiany stosownych gruntów ${ }^{11}$.

Dalsze pozyskiwanie nieruchomości na cele kurortu rysuje się mniej jasno. Cesarz Franciszek I w swoim rozporządzeniu z 11 sierpnia 1808 roku, dotyczącym rozbudowy uzdrowiska w Krynicy, zlecił dokonanie wielkiej wymiany gruntów. W myśl tego dekretu podlegało jej aż 91 mórg 1562 sążnie ziem należących do poddanych (86 mórg 1330 sążni) oraz do probostwa greckokatolickiego (6 mórg 232 sążnie). Poszkodowani mieli uzyskać analogiczne działki z obszaru dóbr dominialnych. O rozporządzeniu tym pisał do Gubernium 25 marca 1813 roku hr. Josef Wallis, prezydent Kamery Nadwornej. Czy transakcja ta została wówczas faktycznie przeprowadzona, jasno z pisma nie wynika. Wydaje się, że przynajmniej wymieniono większość gruntów należących do probostwa grecko-katolickiego (zapewne 5 mórg 338 sążni) ${ }^{12}$.

Zakup i wymiany gruntów prowadzone w latach 1808-1813 stworzyły podstawy do funkcjonowania państwowego uzdrowiska w Krynicy. Ich celem było nabycie źródeł mineralnych, terenów pod budowę domu zdrojowego i budynków gościnnych oraz na założenie ogrodu i większego parku. Skarb państwa był tutaj w korzystnej sytuacji, gdyż z wyjątkiem wywłaszczenia dóbr Jerzego Michałowicza za gotówkę pozostałe transakcje miały charakter wymiany gruntów. A tymi państwo, jako właściciel dominium Muszyna, dysponowało w odpowiedniej ilości. Dlatego też mimo trudnej sytuacji ekonomicznej Austrii (wojny napoleońskie, częściowe bankructwo monarchii w 1811 roku) i braku odpowiednich środków finansowych stworzenie odpowiednich warunków do przyszłego rozwoju kurortu okazało się możliwe.

Poważnych problemów nastręczyło wzniesienie odpowiedniej infrastruktury uzdrowiskowej. Dotychczas istniejące obiekty nie odpowiadały, przynajmniej według władz austriackich, jakimkolwiek standardom. W miejscowości funkcjonowały dwa niezabezpieczone źródła mineralne, poza tym istniał dom zdrojowy (,stary”) oraz gospoda. Co gorsza, Krynica od samego początku istnienia jako kurort borykała

\footnotetext{
${ }^{9}$ CPAHUL, fond 146, op. 77, spr. 13, s. 93.

${ }^{10}$ Ibidem, s. 122-123.

${ }^{11}$ Ibidem, s. 141-150.

${ }^{12}$ Ibidem, spr. 14, s. 5.
} 
się z silną konkurencją pobliskich uzdrowisk węgierskich (w Bardejowie, a właściwie w Bardejowskich Kupelach oraz w Starej Lubowli), a następnie także ze strony galicyjskiej Szczawnicy ${ }^{13}$. Bez wzniesienia przyzwoitych łazienek, budynków noclegowych oraz parku rozwój Krynicy jako kurortu był zupełnie niemożliwy.

Władze gubernialne podjęły w 1807 roku decyzję o budowie pawilonu zabezpieczonego żelazną kratą, który miał chronić główne źródło mineralne w Krynicy. Prace miano ukończyć na sezon 1808 roku. Następną inwestycją miał być ogród przy budynku gościnnym znajdującym się obok źródła mineralnego. Projekty wzniesienia kolejnych obiektów obejmowały: gospodę dla gości, magazyn, basen na wodę mineralną oraz skanalizowanie za pomocą rur żelaznych głównego zdroju. Same rury dostarczyć miała manufaktura w Suchedniowie. W rezultacie podjętych prac obydwa istniejące źródła mineralne miały być chronione za pomocą wzniesionych nad nimi drewnianych budynków ${ }^{14}$.

W latach 1808-1811 podjęto prace przy zabezpieczeniu głównego źródła („Cyryl"), wyrównano powierzchnię gruntów i podjęto budowę kanałów dla wód mineralnych, łączących źródła z domem zdrojowym oraz z nowo otwartym pawilonem, „Lufthausem”. Planowano wzniesienie stajni (piwnicy) z magazynem (wagonownią), rozbudowę obiektów mieszkalnych, zbudowanie dwóch krytych loggii (pawilonów spacerowych), założenie parku, regulację potoku oraz poprawę stanu dróg lokalnych. 7 kwietnia 1808 roku zgodę na budowę traktierni, stajni, wagonowni oraz mieszkania służbowego dla lekarza uzdrowiskowego kosztem $5053 \mathrm{fl}$ wyraził hr. Zichy w imieniu Kamery Nadwornej ${ }^{15}$.

Rozbudowa uzdrowiska traktowana była bardzo poważnie przez władze centralne. Według pisma Kamery Nadwornej z 11 sierpnia 1808 roku cesarz Franciszek I zaakceptował podjęcie w Krynicy następujących inwestycji:

1) Ukończenie grobli regulującej przepływ potoku (Słotwinka);

2) Zbudowanie kanału głównego i rowu dla źródeł mineralnych;

3) Uregulowanie głównego zdroju „Cyryl” oraz zbudowanie przepompowni;

4) Wzniesienie pawilonu ponad źródłem mineralnym;

5) Przebudowę ujęcia wody z zamontowaniem żelaznej kraty oraz wyposażeniem go w naczynia do picia wody;

6) Wzniesienie piwnicy (stajni) dla dzierżawcy oraz magazynu (wagonowni);

7) Wzniesienie lub zaadaptowanie mieszkania dla lekarza zdrojowego ijustycjariusza;

8) Przebudowę starego domu zdrojowego;

9) Założenie ogrodu obok domu gościnnego.

Ogólne koszty tych inwestycji oceniono na $39747 \mathrm{fl}$, a miały zostać przeprowadzone do 1811 roku (w tym pawilony spacerowe i traktiernia) ${ }^{16}$.

${ }^{13}$ Ibidem, spr. 13, s. 160; spr. 14, s. 66. O źródłach mineralnych w Bardejowie i w Starej Lubowli zob. B. Hacquet, Hacquet's neueste physikalisch-politische Reisen, Teil 3, Nürnberg 1794, s. 121-138; Teil 4, Nürnberg 1796, s. 124.

${ }^{14}$ CPAHUL, fond 146, op. 77, spr. 13, s. 51-58.

15 Ibidem, s. 63-88.

${ }_{16}$ Ibidem, s. 96. W 1810 r. i w VIII 1811 r. odwiedził Krynicę gubernator Galicji Peter von Goess, który miał zapewnić dodatkowe finansowanie rozbudowy uzdrowiska. M.J. Adamczyk, Wieś i osada 
Przebieg tych prac jest tylko częściowo uchwytny w źródłach. Wiadomo jedynie, że w latach 1809-1810 zbudowano kanał i most za 3853 fl, mieszkanie dla justycjariusza za $5685 \mathrm{fl}$ oraz groblę i most za $1610 \mathrm{fl}$. Ta ostatnia inwestycja była zapewne kontynuacją budowy wspomnianego wcześniej kanału ${ }^{17}$. Ogólny koszt inwestycji, planowany początkowo w 1808 roku na $43677 \mathrm{fl}$, został następnie nieco zredukowany do kwoty $42680 \mathrm{fl}$, a ostatecznie najprawdopodobniej do wspomnianej już sumy $39747 \mathrm{fl}^{18}$.

Kolejne inwestycje zrealizowano już po zakończeniu wojen napoleońskich. 11 marca 1817 roku Kamera Nadworna zaakceptowała bowiem wydanie $6625 \mathrm{fl} \mathrm{na}$ nowe rury dla wód mineralnych, rynny (w praktyce prymitywne wodociągi) oraz na przepompownię. Prace te wykonano najprawdopodobniej jeszcze w 1816 roku $^{19}$. W świetle tych informacji roboty przeprowadzone w 1808 roku były albo niechlujnie wykonane, albo też dostarczony materiał z manufaktur w Suchedniowie uległ w tym czasie zupełnej destrukcji. Niezależnie od tego sposób prowadzenia tej inwestycji nie świadczył dobrze o austriackim systemie zamówień i ich późniejszej kontroli.

Wraz z podjęciem prac budowlanych aktualności nabrało zatrudnienie lekarza uzdrowiskowego, co w praktyce oznaczać miało uznanie Krynicy za prawdziwy kurort. Wspominał o tym jasno dekret Kamery Nadwornej z 12 marca 1807 roku. Stanowiskiem tym zainteresował się wkrótce protomedyk Neuhauser, jeden z członków komisji powołanej do koordynowania rozbudowy uzdrowiska, który 13 czerwca 1807 roku wystosował pismo do lwowskiego lekarza Johanna Neunela w sprawie zatrudnienia go w Krynicy jako lekarza zdrojowego ${ }^{20}$. W 1808 roku Kamera Nadworna podjęła decyzję o wniesieniu mieszkania służbowego dla lekarza zdrojowego, co może świadczyć o tym, że etat ten mógł już być obsadzony. Zarazem podniesiono roczny koszt utrzymania lekarza zdrojowego z 400 na $600 \mathrm{fl} \mathrm{rocznie}^{21}$.

W 1814 roku krynickie źródła mineralne badali dr Wilhelm Harland i dr Franz Stirba von Stirbitz ${ }^{22}$. Ten ostatni złożył stosowny raport 24 października 1814 roku. Tekst ten nie zawierał jednak informacji o działalności miejscowego lekarza zdrojowego. Inna notatka, przygotowana przez urząd cyrkularny w Nowym Sączu

zdrojowa, s. 213; „Gazeta Lwowska” 1811, nr 1, 2 IV, „Dodatek”, s. 2; „Gazeta Lwowska” 1811, nr 50, 20 IX, „Dodatek”, s. 1.

${ }^{17}$ CPAHUL, fond 146, op. 77, spr. 13, s. 127-134.

${ }_{18}$ Ibidem, spr. 14, s. 61. Według Bolesława Skórczewskiego koszt inwestycji w 1. 1808-1812 wyniósł 44655 fl, względnie $61328 \mathrm{fl}$ (ta ostatnia kwota wydaje się dość zawyżona). B. Skórczew ski, Historia Krynicy, „Przegląd Zdrojowy” 1906, nr 6, s. 3; E. Kaczmarska (Wartości historyczno-estetyczne architektury $i$ urbanistyki Krynicy [w:] Krynica, op. cit., s. 346), podaje wykaz istniejących obiektów w Krynicy z 1820 r., który odpowiada wzmiankowanym inwestycjom oraz budowlom umieszczonym w tabeli opłat za $1811 \mathrm{r}$.

${ }^{19}$ CPAHUL, fond 146, op. 77, spr. 14, s. 54.

${ }^{20}$ Ibidem, spr. 13, s. 39, 50. Według Bolesława Skórczewskiego to dr Neunel został lekarzem zdrojowym w Krynicy. Jest to jednak chyba nadinterpretacja źródeł. B. Skórczewski, Historia Krynicy, „Przegląd Zdrojowy" 1906, nr 6, s. 3.

${ }^{21}$ CPAHUL, fond 146, op. 77, spr. 13, s. 86, 96.

${ }^{22}$ Franz Stirba von Stirbitz (1780-1832), austriacki lekarz urodzony w rodzinie urzędniczej w Nowym Sączu, badacz krynickich źródeł mineralnych oraz krynicki lekarz zdrojowy. Österreichisches Biographisches Lexikon 1815-1950, Bd. 13, Wien 2009, s. 269. 
25 stycznia 1815 roku, informowała o niebezpiecznych przypadkach zachorowania wśród kuracjuszy, ale sporządzona została najprawdopodobniej przez urzędnika niemającego większego rozeznania medycznego ${ }^{23}$. Z późniejszych raportów, między innymi z 30 września 1820 roku można wnioskować, że dr Stirba von Stirbitz nie tylko przebywał w uzdrowisku, lecz także zabierał głos na temat wartości tamtejszych źródeł mineralnych. Według Schematyzmu na 1822 rok był on lekarzem uzdrowiskowym w Krynicy. Stoi to jednak w sprzeczności z raportem starostwa cyrkularnego w Nowym Sączu z 20 listopada 1822 roku. Znalazł się w nim bowiem postulat zatrudnienia stałego lekarza zdrojowego w Krynicy, gdyż większość przyjezdnych stanowili chorzy, a nie goście przyjeżdżający dla rozrywki ${ }^{24}$. Ostatecznie posadę lekarza zdrojowego zatrzymał Stirba von Stirbitz, który w pismach Gubernium z lat 1829-1830 występował stale jako lekarz „kąpielowy” (zdrojowy). W lipcu 1830 roku doznał ataku apopleksji, co zapewne zakończyło jego działalność zawodową w Krynicy. Zmarł w „swoim” uzdrowisku niespełna dwa lata później ${ }^{25}$.

Niejasno przedstawia się bezpośredni zarząd nad uzdrowiskiem. Władze państwowe planowały je wydzierżawić już w 1807 roku za stosowną opłatą. W następnym roku w kilku pismach była mowa o dzierżawcy nazwiskiem Hofmann (Georg Hofmann), który miał przejąć oficjalnie kontrolę nad funkcjonowaniem zdroju. Czy jednak rzeczywiście do tego doszło, a jeżeli tak, to kiedy? Na ten temat źródła gubernialne milczą. W piśmie z 25 września 1810 roku wystąpił Johann Böhm, jako komisarz zdrojowy w Krynicy, natomiast raport z zakończenia sezonu 1810 roku sporządził justycjariusz z Muszyny, Paul Mestnovich. Brak wzmianki o dzierżawcy sugerowałby, że uzdrowisko znajdowało się wciąż pod zarządem urzędników państwowych. Wiadomo natomiast, że latem 1813 roku dzierżawcą krynickiej traktierni był Kowiński (Kowieński, Kowięcki), który w raporcie z 9 kwietnia 1819 roku wymieniony został już jako dzierżawca całego uzdrowiska ${ }^{26}$.

${ }^{23}$ CPAHUL, fond 146, op. 77, spr. 14, s. 25, 41. Drukowana wersja raportu Stirby ukazała się we Lwowie (F. Stirba von Stirbitz, Die Mineralquelle zu Krynica im Sandezer Kreise in Ostgalizien, Lemberg 1816); B. Eble, Versuch einer pragmatischen Geschichte der Arzneikunde, Wien 1840, s. 553.

${ }^{24}$ Schematismus des Königreiches Galizien und Lodomerien für das Jahr 1822, Lemberg 1822, s. 199; CPAHUL, fond 146, op. 77, spr. 14, s. 72-73, 85. Informacja podana przez Bolesława Skórczewskiego, że w 1. 1808-1812 lekarzem zdrojowym był dr Wilhelm Harland, a od 1813 r. dr Franz Stirba nie znajduje jednoznacznego potwierdzenia w zachowanym materiale źródłowym. B. Skórczewski, Historia Krynicy, „Przegląd Zdrojowy” 1906, nr 6, s. 2. Mieczysław Adamczyk podaje (za czasopiśmiennictwem XIX-wiecznym), że pierwszym lekarzem w Krynicy był dr Józef Nennel (1807-1808), w 1. 1809-1814 dr Wilhelm Harland, a w 1. 1814-1832 dr Franz Stirba. Te dane też nie są w pełni poprawne. M.J. Adamczyk, Wieś i osada zdrojowa, s. 214-216. O nominacji dr Harlanda na lekarza zdrojowego w Krynicy donosił „Dodatek” do „Gazety Lwowskiej” 1811, nr 1, 2 IV. Nie był on natomiast uwzględniony (podobnie jak sam etat lekarza zdrojowego) w Schematyzmie na $1812 \mathrm{r}$.

${ }_{25}$ CPAHUL, fond 146, op. 77, spr. 14, s. 122, 127, 137; B. Skórczew ski, Historia Krynicy, „Przegląd Zdrojowy" 1906, nr 7, s. 3-4. Nie przeszkodziło to odnotować Franza Stirby jako rzekomo wciąż żyjącego lekarza zdrojowego w Krynicy w 1834 r. A.C.P. Callis en, Medicinisches Schriftstellers-Lexicon der jetzt lebenden Aerzte, Wundärzte, Geburtshelfer, Apotheker und Naturforscher aller gebildeten Völker, Bd. 18, Copenhagen 1834, s. 424.

${ }^{26}$ CPAHUL, fond 146, op. 77, spr. 13, s. 58, 96, 122-123, 159-160; spr. 14, s. 30, 66; Schematismus des Königreiches Galizien und Lodomerien für das Jahr 1812, Lemberg 1812, s. 119. Według Bolesława 
Jak funkcjonowało uzdrowisko w tym okresie? Informacji na ten temat jest stosunkowo niewiele. Najwięcej przynosi raport wspomnianego już Mestnovicha, sporządzony 24 września 1810 roku. Według niego stali kuracjusze pili regularnie wodę mineralną i korzystali z kąpieli. Oprócz nich pojawili się jednodniowi przyjezdni z Bardejowa, Lubowli oraz z Nowego Sącza, którzy korzystali z kąpieli, a przebywali po części w zdroju, a po części u chłopów i nie zostali ujęci w oficjalnej statystyce frekwencji.

Mestnovich zwracał uwagę na problemy finansowe kurortu. Według niego goście odmawiali uiszczania opłat na fundusz upiększenia uzdrowiska, szczególnie ci z zagranicy, natomiast personelowi nie starczało środków finansowych na niezbędne potrzeby. Część gości unikała wynajmowania kwater w domu gościnnym, zwłaszcza przyjezdni z Węgier (Bardejowa i Lubowli), którzy przebywali dłużej na kuracji po drugiej stronie granicy. Pewien problem wywoływały nielegalne gry karciane o charakterze szulerki, nie były one jednak powszechne.

Autor raportu zwracał także uwagę na możliwości uatrakcyjnienia pobytu w Krynicy. Sądził, że należy postarać się o odpowiednią salę balową oraz zorganizowanie orkiestry, jak również rozpoczęcie wystawiania przedstawień teatralnych. Mestnovich proponował, by orkiestra nie tylko przygrywała podczas zabaw tanecznych, lecz by koncertowała codziennie w sali balowej, a w dobrą pogodę także na świeżym powietrzu. W tym celu sugerował nałożenie dodatkowej opłaty w wysokości $2 \mathrm{fl}$ na kuracjusza, by zapewnić podstawy materialne muzykom ${ }^{27}$.

Koszt pobytu kuracjuszy w Krynicy przedstawiony został w projekcie taryfy na sezon 1811 roku Stawki były następujące ${ }^{28}$ :

- za pokój: 30 krajcarów w złocie lub 2 fl $30 \mathrm{kr}$ w bankocetlach dziennie w domu gościnnym;

- za pokój: $15 \mathrm{kr} / 1 \mathrm{fl} 15 \mathrm{kr}$ dziennie w budynku [Hebergebäude] obok starej stajni;

- za pokój: $15 \mathrm{kr} / 1 \mathrm{fl} 15 \mathrm{kr}$ dziennie w drewnianym budynku naprzeciw lazienek;

- za pokój: $12 \mathrm{kr} / 1 \mathrm{fl}$ dziennie w starym budynku zdrojowym;

- za pokój kąpielowy: 12 fl/1 fl dziennie;

- za inną łazienkę: $9 \mathrm{kr} / 45 \mathrm{kr}$ dzienne;

- za duży albo podwójny pokój kąpielowy: $24 \mathrm{kr} / 2 \mathrm{fl}$ dziennie (mniejszy/prostszy: $18 \mathrm{kr} / 1 \mathrm{fl} 30 \mathrm{kr})$;

- stawka dla gości mieszkających na wsi (poza uzdrowiskiem) i korzystających z wód mineralnych: $8 \mathrm{kr} / 40 \mathrm{kr}$ dziennie (za beczkę wody liczącą 36 garncy);

- za beczółkę zimnej wody mineralnej do własnego naczynia: $2 \mathrm{kr} / 10 \mathrm{kr}$;

Skórczewskiego w 1805 r. dzierżawę Krynicy objął Johann Hecht, w 1806 r. Bosewitz, w 1808 r. Georg Hofmann, w 1810 r. Kowięcki, w 1820 r. Adam Pohlmann. Podane daty działania i nazwiska dwóch pierwszych dzierżawców budzą jednak wątpliwości, wydaje się nadto, że przez znaczną cześć tego okresu uzdrowisko znajdowało się pod bezpośrednią administracją zarządu dominalnego w Muszynie. B. Skórczewski, Historia Krynicy, „Przegląd Zdrojowy” 1906, nr 6, s. 2.

${ }^{27}$ CPAHUL, fond 146, op. 77, spr. 13, s. 160. Inicjatorem wprowadzenia opłaty na upiększenie uzdrowiska (2 fl na kuracjusza na sezon) był Joseph August Schultes. S. Schnür-Pepłowski, Cudzoziemcy w Galicji, s. 144.

${ }^{28}$ CPAHUL, fond 146, op. 77, spr. 13, s. 170. 
- opłata za przechowywanie konia: $3 \mathrm{kr} / 15 \mathrm{kr}$ dziennie;

- opłata za przechowywanie wozu: $9 \mathrm{kr} / 45 \mathrm{kr}$ dziennie;

- za skrzynkę kwaśnej wody mineralnej (20 flaszek): 6 fl $12 \mathrm{kr} / 31 \mathrm{fl}$;

- za 1 butelkę (do własnego opakowania) kwaśnej wody mineralnej: 6 kr/30 kr.

Na podstawie tych danych można uznać, że pobyt w uzdrowisku, a szczególnie w domu gościnnym (zdrojowym), nie należał do najtańszych. Nie należy się zatem dziwić, że część gości wybierała prymitywne pomieszczenia u chłopów, zadowalając się kąpielami w najprostszych warunkach.

Kwestie finansowe były zmorą Krynicy także w kolejnych latach. Według raportu z 9 kwietnia 1819 roku w uzdrowisku funkcjonowały dwa źródła mineralne, ale konieczne było obniżenie niektórych cen kąpieli na sezon 1819. Przeciętna cena za łazienkę wynosić miała $30 \mathrm{kr} /$ dziennie i tyle samo kosztować miało dostarczenie beczki wody do domów wiejskich. Widać jasno, że do tego czasu spora część gości unikała łazienek zdrojowych, najwyraźniej zakładając, że sprowadzenie wody mineralnej do chałupy będzie znacznie tańsze. Jednocześnie dzierżawca domagał się podniesienia stawki za pokój w budynkach zdrojowych z $45 \mathrm{kr}$ na $1 \mathrm{fl} 20 \mathrm{kr}$ dziennie. Argumentował przy tym dość pokrętnie, że tutejsze zimne wody mineralne miały być mniej wartościowe dla zdrowia niż te w Szczawnicy i Bardejowie, a konkurencji z tym ostatnim nie sposób było wygrać 29 .

Nie najlepiej przedstawiała się sprawa rozreklamowania uzdrowiska w Krynicy. W 1807 roku Kamera Nadworna planowała wykorzystać gazety czeskie i morawskie jedynie do szerzenia wiadomości o przetargu na dzierżawę uzdrowiska, pomijając milczeniem rozpropagowanie kurortu w samym społeczeństwie ${ }^{30}$. Dopiero w kwietniu 1811 roku na łamach półurzędowej „Gazety Lwowskiej” zamieszczono w „Dodatku" specjalny artykuł poświęcony walorom uzdrowiskowym Krynicy, a wkrótce ponownie zwrócono na nią uwagę w tej samej gazecie przy okazji wizyty gubernatora Galicji Petera von Goessa w zdroju. Można jedynie domniemywać, że publikacje te były wspierane przez galicyjskie Gubernium i stanowiły element promocji nie tylko samej Krynicy, lecz także administracji austriackiej w Galicji31.

Wraz z załamaniem się frekwencji na początku drugiej dekady XIX wieku logiczne byłoby silniejsze wsparcie reklamowe uzdrowiska. W raporcie Gubernium do Kamery Nadwornej z 9 kwietnia 1819 roku pisano jasno o konieczności rozreklamowania Krynicy za pomocą gazet lwowskich, krakowskich, warszawskich i wileńskich, co dość dobrze oddaje aspiracje zarządu uzdrowiska skierowania swojej oferty nie tylko na całość ziem zaboru austriackiego, lecz także na Wolne Miasto Kraków, Królestwo Polskie i Ziemie Zabrane ${ }^{32}$. W kolejnych miesiącach sytuacja nie uległa jednak poprawie, a w społeczeństwie galicyjskim zaczęły się szerzyć opinie o kiepskiej jakości wód krynickich, czy też może nawet całego uzdrowiska. Przeciwdziałać tym niekorzystnym plotkom zamierzano przez publikację stosownych artykułów

29 Ibidem, sprawa 14, s. 66.

30 Ibidem, sprawa 13, s. 39.

31 „Gazeta Lwowska” 1811, nr 1, 2 IV, „Dodatek”, s. 2; „Gazeta Lwowska” 1811, nr 50, 20 IX, „Dodatek”, s. 1.

32 CPAHUL, fond 146, op. 77, spr. 14, s. 66. 
oraz druków ulotnych. Postulował to dr Stirba von Stirbitz na zakończenie sezonu 30 września 1820 roku oraz starostwo cyrkularne w Nowym Sączu w raporcie z 25 stycznia 1821 roku $^{33}$.

Czy jednak powtarzające się postulaty zorganizowania poważnej akcji reklamowej na rzecz Krynicy, a już szczególnie na łamach zagranicznych gazet, doprowadziły do konkretnych działań? Zachowane materiały Gubernium milczą na ten temat. Wydaje się zatem, że ograniczono się głównie do projektów. Nieliczne materiały propagujące uzdrowisko (niemieckojęzyczne teksty naukowe, artykuły w „Gazecie Lwowskiej”) były dziełem osób związanych z administracją austriacką i samym Gubernium, ale raczej stanowiły wynik ich samodzielnych inicjatyw niż przemyślanej akcji o charakterze państwowym. Zasięg oddziaływania tych druków pozostawał zresztą niewielki.

Twarde dane na temat popularności Krynicy przynoszą oczywiście informacje o frekwencji. W aktach Gubernium są one zachowane wyrywkowo, a ponadto nie zawsze były konstruowane według tej samej metodologii. Mimo wszystko sporo z nich wynika i pozwalają na zrekonstruowanie ogólniejszych trendów

Dla 1807 roku była mowa o 171 kuracjuszach. Dane te są najprawdopodobniej zaniżone, gdyż uwzględniały „gości” (a w praktyce „głowy rodzin”) bez względu na to, czy przebywali tu samotnie, czy też z rodzinami. W 1810 roku przebywało w Krynicy 180 rodzin kuracjuszy, razem 532 osoby. Oprócz nich nieujęci w statystyce zostali jednodniowi przyjezdni z Bardejowa, Lubowli oraz z Nowego Sącza. W kolejnych latach frekwencja wyraźnie spadła. Według raportu sądeckich władz cyrkularnych do Gubernium z 25 stycznia 1815 wpływ na to negatywne zjawisko mogła mieć nagła śmierć szlachcica Jordana pochodzącego z Piasków w cyrkule bocheńskim. Miała ona rozpowszechnić negatywne oceny wartości tutejszych źródeł. Niepokój władz cyrkularnych wywołała także nagła choroba (gorączka) pani von Szymsiewicz oraz jej siostry panny Łubińskiej pochodzących z cyrkułu tarnowskiego. Wpływ na ich choroby mogło mieć „ostre górskie powietrze”34. Następne lata nie przyniosły Krynicy tendencji wzrostowych. W 1820 roku odnotowano w niej zaledwie 46 rodzin (185 osób) oraz 56 rodzin na krótki pobyt, w 1821 roku już tylko 40 rodzin (148 osób) oraz 12 rodzin na krótki pobyt, natomiast w 1822 roku 54 rodziny (189 osób) oraz 34 rodziny na krótki pobyt. Pod koniec dekady sytuacja nieco się poprawiła. W 1829 roku do Krynicy bowiem zjechało 81 rodzin (258 osób), którym wydano 4242 kąpiele ${ }^{35}$.

33 Ibidem, s. 72.

34 Ibidem, s. 25. Problem ewentualnego wpływu pandemii występujących w Galicji na frekwencję kuracjuszy w Krynicy jest niejasny. Masowe zachorowania na tyfus odnotowano w zaborze austriackim m.in. w 1806 i 1808 r., a były one roznoszone głównie przez wojskowych (w poszczególnych pułkach zmarło ponad 20\% wszystkich żołnierzy). Nie wpłynęły one jednak negatywnie na frekwencję w uzdrowiskach. Po 1815 r. skala pandemii (poza 1831 r.) nie wydaje się wyższa niż w dobie wojen napoleońskich, a mimo to nastąpiło wówczas zahamowanie tendencji wzrostowych wśród kuracjuszy w Krynicy. Zob. M. Baczkowski, Nie na polu chwaty. Straty osobowe armii austriackiej w dobie wojen napoleońskich z przyczyn niebojowych [w:] Amigo, socio et viro docto. Ksiega ku czci profesora Andrzeja Kazimierza Banacha, red. T. Pudłocki, K. Stopka, Kraków 2015, s. 29-40.

35 CPAHUL, fond 146, op. 77, spr. 13, s. 51, 160; spr. 14, s. 85, 88, 116, 122 . Nieco inne, choć na ogół zbliżone liczby podaje Bolesław Skórczewski. Wydaje się poza tym, że nie zawsze rozróżnia pojedynczych kuracjuszy od całych rodzin (głów rodzin). B. Skórczewski, Historia Krynicy, „Przegląd 
Posiadamy z niektórych lat informacje o pochodzeniu geograficznym gości. W 1820 roku na 46 zarejestrowanych rodzin 5 pochodziło z Królestwa Polskiego (z Warszawy, Lublina, Sandomierza, Wodzisławia), 3 z Wolnego Miasta Krakowa, a 38 z Galicji. Wśród kuracjuszy galicyjskich dominowały osoby pochodzące z pobliskich cyrkułów: sądeckiego, tarnowskiego, rzeszowskiego i bocheńskiego. Pojedynczy przybysze przyjechali z cyrkułu wadowickiego oraz ze Lwowa. W 1829 roku na 81 zarejestrowanych rodzin 9 pochodziło z Królestwa Polskiego (na ogół z miejscowości położonych na południe od Warszawy), kolejnych 13 z Wolnego Miasta Krakowa, a 59 z Galicji (głównie z okolicznych cyrkułów oraz ze Lwowa). Wynika stąd dość jasno, że obszar oddziaływania uzdrowiska był stosunkowo niewielki: pięć sąsiadujących z sobą cyrkułów Galicji i Lwów, a z zagranicy: Wolne Miasto Kraków oraz południowe obszary Królestwa Polskiego (głównie województwo krakowskie i sandomierskie).

Skład społeczny kuracjuszy na pewno niezbyt satysfakcjonował zarząd zdroju. W 1820 roku wśród przybyszów dominowało drobne ziemiaństwo i zarządcy dóbr, następnie urzędnicy prowincjonalni, pojedynczy prawnicy i lekarze. Odnotowano nadto jednego księdza i co najmniej 4 rodziny żydowskie (z Galicji i z Królestwa Polskiego). Obok przeważających liczebnie Polaków pojawiły się pojedyncze rodziny niemieckie (głównie urzędników galicyjskich). Nieco inaczej prezentowała się grupa gości krótkoterminowych. Wśród nich oprócz ziemian byli urzędnicy oraz dość liczni oficerowie austriaccy, najczęściej z cyrkułu sądeckiego. W tej grupie była znaczniejsza reprezentacja Niemców austriackich.

Według danych z 1829 roku pochodzenie społeczne kuracjuszy nie uległo większym zmianom. Byli wśród nich ziemianie (w tym zaledwie jeden arystokrata, hr. Józef Potocki), urzędnicy, przedstawiciele wolnych zawodów, mieszczanie i przedsiębiorcy (częściowo żydowscy, między innymi z Krakowa) ${ }^{36}$. Wśród kuracjuszy brakowało zatem zamożnej arystokracji, przedstawicieli elit polityczno-administracyjnych oraz bogatej, wielkomiejskiej burżuazji. Polacy, szczególnie należący do tych dwóch pierwszych grup, wybierali w tym czasie czołowe kurorty europejskie położone przeważnie w Czechach ${ }^{37}$.

Dlaczego Krynica nie zdołała wówczas zdobyć większej popularności? Dla mieszkańców Krakowa i okolic ciekawszą propozycją od dość odległej Krynicy były prywatne uzdrowiska w pobliskich Krzeszowicach (istniejące od ok. 1780 r., a rozbudowane w 1819 r.) oraz w Swoszowicach (otwarte w 1811 r.) ${ }^{38}$. Szczególnie Krzeszowice sprawiały bardzo dobre wrażenie jako zadbany i pięknie położony kurort,

Zdrojowy" 1906, nr 6, s. 2; nr 7, s. 4. Niepełne i także nieco rozbieżne dane zamieścił M.J. Ada mczyk, Wieś i osada zdrojowa, tab. 5.

${ }^{36}$ CPAHUL, fond 146, op. 77, spr. 14, s. 85, 116.

${ }^{37}$ W 1. 1816-1817 na kuracji w Karlsbadzie przebywali m.in. ks. Maria z Czartoryskich Wirtemberska z siostrą Cecylią Beydale, gen. Tomasz Łubieński z żoną, gen. Karol Kniaziewicz, rodziny Wielopolskich i Sobańskich, a także tacy prominentni goście jak król pruski Fryderyk Wilhelm III, kanclerz pruski ks. Karl August Hardenberg, feldmarszałek pruski Gebhard Leberecht Blücher. M. Brandys, Koniec świata szwoleżerów, cz. I, Warszawa 1972, s. 204-214.

38 Stownik Geograficzny Królestwa Polskiego i innych krajów słowiańskich, t. IV, Warszawa 1883, s. 789; t. XI, Warszawa 1890, s. 730; „Gazeta Lwowska” 1817, „Rozmaitości”, nr 10, 5 V, s. 74. 
o czym z uznaniem pisał Samuel Bredetzky w 1808 roku $^{39}$. Z tych źródeł mineralnych korzystał na przykład ks. Józef Poniatowski podczas kilkumiesięcznego pobytu w Krakowie w 1809 roku $^{40}$.

Także powolny rozwój pobliskiej Szczawnicy (od ok. 1828 r., chociaż na walory jej źródeł jako potencjalnej konkurencji zwracano uwagę już w 1819 r.), Krościenka (od 1827 r.) oraz uzdrowisk położonych w południowej części Królestwa Polskiego (Solec od 1824 r., Busko od 1826 r.) stawał się coraz poważniejszą konkurencją dla Krynicy pod koniec trzeciej dekady XIX wieku ${ }^{41}$. Dla stołecznego Lwowa Krynica była już bardzo oddalona, a ponadto w stosunkowo niewielkiej odległości od miasta były czynne trzy uzdrowiska: w Szkle, Lubieniu i Truskawcu, skutecznie absorbujące wielu lwowskich kuracjuszy ${ }^{42}$.

Czy rozbudowa Krynicy spełniła oczekiwania władz austriackich? Odpowiedź jest jednoznaczna: nie. Zamierzenia czynników państwowych oraz krajowych, galicyjskich, były dość ambitne, chociaż nigdy nie zostały jasno wyartykułowane. Bez wątpienia zakładano, że Krynica stanie się stosunkowo szybko jednym z głównych uzdrowisk Galicji i będzie przyciągać zróżnicowaną klientelę, przede wszystkim polską, także spoza ziem zaboru austriackiego ${ }^{43}$. Plany te nie były zupełnie pozbawione podstaw. Liczba uzdrowisk galicyjskich była na przełomie XVIII i XIX wieku niewielka, ich standard niski, natomiast liczba potencjalnych kuracjuszy z ziem polskich (arystokracja, ziemiaństwo, burżuazja miejska, przedstawiciele warstw urzędniczych i wojskowych) wydawała się dość znaczna.

Założenia władz okazały się jednak błędne. Krynica ściągnęła większą liczbę gości tylko w końcowym okresie rozbudowy (ok. 1810 r.) i to pomimo chaosu związanego z przegraną wojną z Napoleonem w 1809 roku oraz częściowym podziałem Galicji, której znaczna część wraz z Krakowem została włączona do Księstwa Warszawskiego. W następnych latach frekwencja raptownie spadła. Wydaje się, że dla znacznej części klienteli istotnym problemem był kryzys finansowy państwa austriackiego w 1811 roku, prowadzący do załamania kursu waluty papierowej i częściowego bankructwa monarchii. Wielki drenaż finansowy Galicji związany z finansowaniem kampanii antynapoleońskich w latach 1813-1815 dodatkowo pogłębił pauperyzację ludności. Perturbacje gospodarcze negatywnie wpłynęły na możliwości finansowe całej rzeszy mieszkańców Galicji, zahamowały też procesy inwestycyjne w uzdrowisku. O niedokończonym dziele rozbudowy kurortu świadczyć może problem ze

${ }^{39}$ S. Bredetzky, Reisebemerkungen über Ungarn und Galizien, Bd. II, Wien 1809, s. 82-83. (Koszt wynajęcia w Krzeszowicach wygodnego mieszkania dwupokojowego wraz jadalnią, kuchnią i łazienką wynosił w 1808 r. 2 fl, ibidem).

${ }^{40}$ M. Baczkowski, Wojsko polskie w napoleońskim Krakowie, Kraków 2009, s. 85.

${ }^{41}$ CPAHUL, fond 146, op. 77, spr. 14, s. 66; Stownik Geograficzny Królestwa Polskiego i innych krajów stowiańskich, t. I, Warszawa 1880, s. 479; t. XI, Warszawa 1890, s. 46, 823. Balthasar Hacquet wspominał jeszcze o źródłach mineralnych znanych ok. 1788 r. w Obidzy pod Piwniczną oraz w Szczawie i w Koninie, ale nie były one w ogóle eksploatowane. B. Hacquet, Hacquet’s neueste physikalisch-politische Reisen, Teil 4, s. 124, 141.

42 Opisując te uzdrowiska w 1806 r., Joseph August Schultes ocenił bardzo krytycznie ich standard i warunki oferowane w nich kuracjuszom. S. Schnür-Pepłowski, Cudzoziemcy w Galicji, s. 131-133.

${ }^{43}$ CPAHUL, fond 146, op. 77, spr. 14, s. 66; „Gazeta Lwowska” 1811, nr 1, 2 IV, „Dodatek”, s. 1-4. 
znalezieniem poważnego dzierżawcy, kilkuletni brak lekarza zdrojowego, a wreszcie zarzucenie koncepcji nadania Krynicy charakteru leczniczo-rozrywkowego (porzucenie idei zaangażowania stałej orkiestry oraz sezonowego teatru) na rzecz funkcji czysto medycznych. Władze państwowe, tak aktywne w pierwszej dekadzie XIX wieku, utraciły swój impet inwestycyjny, zadowalając się najwyraźniej faktem, że zdrój w ogóle zaczął funkcjonować ${ }^{44}$.

Niewielki wzrost frekwencji, który nastąpił w latach 20. XIX wieku, po przezwyciężeniu zapaści gospodarczej będącej skutkiem wojen napoleońskich i ponownego częściowego bankructwa Austrii w 1820 roku, nie nadał uzdrowisku silnego impulsu rozwojowego, i to pomimo faktu, że ponad $25 \%$ gości pochodziło z zagranicy. W rezultacie Krynica funkcjonowała, a może raczej wegetowała, wiele lat jako podrzędny kurort austriacki omijany szerokim łukiem przez najbogatszą i najbardziej prestiżową klientelę ${ }^{45}$.

Zachowane materiały lwowskiego Gubernium nie dają pełnej odpowiedzi na to, jak władze krajowe i państwowe zamierzały rozwijać uzdrowisko w Krynicy, szczególnie po kongresie wiedeńskim. Zarzucono wówczas ambitniejsze projekty z lat 1807-1810, ograniczając się do utrzymania istniejącej już infrastruktury i inkasowania należności za pobyt dość nielicznych kuracjuszy. Archiwalia wytworzone po 1815 roku, a szczególnie z lat 20. XIX wieku, stwarzają wrażenie, że władze gubernialne przestały interesować się rozwojem zdroju. Jest o to tyle zrozumiałe, iż wówczas nastąpił proces nasilonego zbywania dóbr kameralnych nabywcom prywatnym, co było rezultatem kryzysu finansowego monarchii po wojnach napoleońskich. Przyszłość majątku państwowego w Galicji stanęła pod znakiem zapytania.

Krynica, jako uzdrowisko państwowe, coraz wyraźniej zaniedbywane, nie stała się wówczas ośrodkiem przyciągającym Polaków ze wszystkich ziem byłej Rzeczypospolitej, na co wcześniej tak liczyło Gubernium i miejscowy zarząd. Brak jasnych koncepcji rozbudowy i rozpropagowania zdroju w epoce powszechnego pokoju i stabilizacji oraz równocześnie zachodzącego procesu rozwoju ośrodków konkurencyjnych w Galicji i w Królestwie Polskim wystawia niskie oceny ówczesnym władzom austriackim. Ambitny projekt z początku XIX stulecia stworzenia ze środków państwowych ważnego kurortu monarchii habsburskiej na północnych skłonach Karpat zakończył się wówczas niepowodzeniem.

${ }^{44}$ Paradoksalnie w 1. 1818-1823 zbudowano zasadniczą część II traktu cesarskiego w Galicji (trakt podkarpacki; Biała-Sucha-Nowy Sącz-Jasło-Sanok-Stryj-Lwów), który w istotny sposób poprawił dostępność komunikacyjną Krynicy. Nie miało to jednak bezpośredniego przełożenia na frekwencję kuracjuszy, a materiały Gubernium dotyczące uzdrowiska w Krynicy całkowicie pomijają tę inwestycję, M. Tobiasz, Jak budowano trakt podkarpacki w 1818-1823 r., „Wierchy”, R. XXX, 1961, s. 187-192.

${ }_{45}$ Apogeum tych negatywnych procesów nastąpiło po powstaniu listopadowym. W latach 40. XIX w. uzdrowisko podupadło zupełnie, część infrastruktury uległa dewastacji, a frekwencja nie zbliżała się nawet do poziomu 200 osób rocznie i wykazywała tendencję malejącą (minimum to 60 kuracjuszy w 1841 i 1849 r.). B. Skórczewski, Historia Krynicy, „Przegląd Zdrojowy” 1906, nr 7, s. 4. Według Franciszka Kmietowicza najniższą frekwencję odnotowano w 1840 r. (57 osób), natomiast przytoczona wyjątkowo wysoka liczba kuracjuszy w 1832 r. (433 osoby) wydaje się błędem cyfrowym (zapewne 133 osoby). F. Kmietowicz, op. cit., s. 13. 


\section{BIBLIOGRAFIA}

\section{Źródła rękopiśmienne}

Центральний державний історичний архів України, Львів [Centralne Państwowe Archiwum Historyczne Ukrainy we Lwowie (CPAHUL)]

Fond 146, op. 77, spr. 13-14

\section{Prasa}

„Gazeta Lwowska” 1811, 1817.

\section{Źródła drukowane i opracowania}

Adamczyk M.J., Wieś i osada zdrojowa w okresie austriackim [w:] Krynica, red. F. Kiryk, Kraków 1994.

Baczkowski M., Nie na polu chwaty. Straty osobowe armii austriackiej $w$ dobie wojen napoleońskich z przyczyn niebojowych [w:] Amigo, socio et viro docto. Księga ku czci profesora Andrzeja Kazimierza Banacha, red. T. Pudłocki, K. Stopka, Kraków 2015.

Baczkowski M., Wojsko polskie w napoleońskim Krakowie, Kraków 2009.

Brandys M., Koniec świata szwoleżerów, Cz. I, Warszawa 1972.

Bredetzky S., Reisebemerkungen über Ungarn und Galizien, Bd. II, Wien 1809.

Callis en A.C.P., Medicinisches Schriftstellers-Lexicon der jetzt lebenden Aerzte, Wundärzte, Geburtshelfer, Apotheker und Naturforscher aller gebildeten Völker, Bd. 18, Copenhagen 1834.

Eble B., Versuch einer pragmatischen Geschichte der Arzneikunde, Wien 1840.

Hacquet B., Hacquet's neueste physikalisch-politische Reisen in den Jahren 1788-1795 durch die Dacischen und Sarmatischen oder Nordlichen Karpathen, Teil III, Nürnberg 1794; Teil IV, Nürnberg 1796.

Kaczmarska E., Wartości historyczno-estetyczne architektury i urbanistyki Krynicy [w:] Krynica, red. F. Kiryk, Kraków 1994.

Kmietowicz F., Z Podkarpacia Zachodniego, Kraków 1936.

Rajchel L., Raj chel J., Krynica-Zdrój- historia uzdrowiska, „Borgis-Balneologia Polska” 2005, nr 1-2.

Österreichisches Biographisches Lexikon 1815-1950, Bd. 2, Wien 1959; Bd. 13, Wien 2009.

Schematismus des Königreiches Galizien und Lodomerien für das Jahr 1812, Lemberg 1812.

Schematismus des Königreiches Galizien und Lodomerien für das Jahr 1822, Lemberg 1822.

Schematismus für die Königreiche Galizien und Lodomerien für das Jahr 1807, Lemberg 1807.

Schnür-Pepłowski S., Cudzoziemcy w Galicji (1787-1841), Kraków 1902.

Skórczews ki B., Historia Krynicy, „Przegląd Zdrojowy” 1906, nr 6-7.

Słownik Geograficzny Królestwa Polskiego i innych krajów słowiańskich, T. I, Warszawa 1880; T. IV, Warszawa 1883; T. XI, Warszawa 1890. 
Ślusarek K., W przededniu autonomii. Własność ziemska i ziemiaństwo w Zachodniej Galicji w połowie XIX wieku, Kraków 2013.

To bias z M., Jak budowano trakt podkarpacki w 1818-1823 roku, „Wierchy”, R. XXX, 1961. Wurzbach C., von, Biographisches Lexikon des Kaiserthums Oesterreich, Bd. I-LX, Wien 1856-1891.

Zieleniewski M., Materiały do historii Zakładu Zdrojowego w Krynicy, „Krynica” 1876, nr 9-12. 